\title{
PERBANDINGAN PEMANFAATAN JURNAL TERCETAK DENGAN JURNAL ELEKTRONIK UNTUK KEBUTUHAN INFORMASI MAHASISWA DI PERPUSTAKAAN UNIVERSITAS SUMATERA UTARA CABANG KEDOKTERAN
}

\author{
Nur'aini*
}

\begin{abstract}
This study aims to compare the utilization of print journals against electronic journals in the information needs of students at the University of Sumatera Utara Branch of Medical Library. Analysis includes the utilization of journals, journal collections according to the user needs. Research method used descriptive with comparative approach. Samples were determined using accidental sampling technique. Data were collected through observation and questionnaires distributed to the students of Bachelor's Degree General Medicine Study Program. Analyses were performed by grouping data from questionnaires and observation. The result of the study showed the majority of students used electronic journals more often than print journals. Overall electronic journals met the information needs of students rather than print journal. In general, students said that electronic journals were more sophisticated than print journals.
\end{abstract}

Keywords: print journal; electronic journals; information needs

* Pustakawan Universitas Sumatera Utara

\section{A. PENDAhULUAN}

Perpustakaan sebagai pusat sumber informasi merupakan tempat untuk menghimpun, mengolah serta menyebarkan informasi yang relevan yang mampu menunjang pelaksanaan penelitian seseorang. Salah satu bahan pustaka berupa sumber informasi di perpustakaan adalah karya ilmiah. Karya ilmiah yang tersedia salah satu berbentuk jurnal.

Jurnal berisi hal-hal yang bersifat ilmiah dan informasinya merupakan hasil dari penelitian para peneliti dan terbit secara berkala. Jurnal menyediakan informasi mutakhir yang terkadang tidak didapat dari sumber bacaan seperti buku. Sifatnya lebih aktual karena sering mempertautkan masalah di lapangan dengan tinjauan teoritis. Jurnal juga dapat dijadikan sebagai bahan referensi dalam penulisan karya ilmiah baru. Dalam perkembanganya jurnal memiliki dua format yang dapat diakses oleh pemustaka yaitu: format tercetak dan format elektronik/digital.

Format tercetak maksudnya jurnal yang fisiknya dibentuk seperti dokumen dan terjilid. Jurnal tercetak informasinya dapat langsung dinikmati ketika jurnal tersebut sudah diterbitkan dalam format buku oleh penerbit. E-Journal dipahami sebagai publikasi ilmiah dalam format elektronik dan mempunyai ISSN (International Standard Serial
Number) yang format dokumennya biasanya HTML dan PDF.

Salah satu upaya Perpustakaan USU dalam memenuhi kebutuhan mahasiswa adalah dengan mengakses jurnal ilmiah yang dibutuhkan sesuai kebutuhan informasi yang diperlukan. Perpustakaan USU Cabang Kedokteran berdiri pada Agustus tahun 2008. Jumlah kunjungan mahasiswa ke Perpustakaan USU Cabang Kedokteran pada tahun 2014 sebanyak 10.083 orang dari mahasiswa SI Program Studi Kedokteran Umum. Perpustakaan USU Cabang Kedokteran memiliki jurnal tercetak pada tahun 2014 berjumlah 115 judul dengan 386 eksemplar bidang kedokteran dan kesehatan, termasuk medical medicine, annual of laboratory medicine, medical science, psychopharmacology and neuroscience, cios, cancer researh, diabetes and metabolism journal, urology, health environment, ilmu kesehatan kulit dan kelamin, indonesian journal of urology, obstetrics, ophtamologi, pyshiatry, radiologi, internal medicine, dan lainlain. Selain jurnal tercetak, Perpustakaan USU melanggan sekitar 7 database jurnal elektronik dengan jumlah sekitar 20.448 judul artikel.

Berdasarkan pengamatan awal, pengguna pada Perpustakaan USU Cabang Kedokteran umumnya menggunakan database jurnal 
elektronik seperti PubMed, e-Medicine, New England Journal of medicine (NEJM) dan MedlinePlus. Hal ini dikarenakan penggunaan jurnal elektronik lebih mudah dan cepat dibanding jurnal tercetak. Jurnal tercetak sering terjadi keterlambatan perolehan informasi, penggunaan dan pelayanan yang terbatas, pemesanan membutuhkan waktu yang lama, tahun terbit yang belum jelas untuk diterbitkan, harga lebih mahal dan jika dilanggan banyak jurnal yang tidak diterbitkan. Selain itu, Perpustakaan USU Cabang Kedokteran mempunyai jurnal tercetak yang diterbitkan sendiri oleh Fakultas Kedokteran yaitu Majalah Kedokteran Nusantara. Jurnal tercetak tersebut tidak diterbitkan kembali, karena Perpustakaan USU Cabang Kedokteran telah banyak melanggan jurnal-jurnal tereetak dari penerbit lain.

Berdasarkan latar belakang masalah, maka dapat dirumuskan masalah yang ditcliti yaitu:

1. Bagaimanakah perbandingan dari pemanfaatan jurnal tercetak dengan jurnal elektronik untuk kebutuhan informasi mahasiswa?

2. Apakah kendala dalam pemanfaatan jurnal tercetak dengan jurnal elektronik di Perpustakaan USU Cabang Kedokteran?

\section{B. TINJAUAN PUSTAKA \\ Jurnal}

Jurnal merupakan salah satu koleksi perpustakaan yang dibutuhkan oleh pengguna untuk menemukan informasi tentang penemuan ilmiah terkini (eurrent). Dalam hal pengelompokkan koleksi perpustakaan, pada dasarnya jurnal termasuk ke dalam kategori koleksi serial.

Adapun pengertian jurnal menurut HighBeamTMResearch, Inc (2012) adalah:

"Journal is the collection and periodic publication or transmission af news and the result of research throughmedia (p.l)"

Artinya bahwa jurnal merupakan suatu koleksi dan terbitan berkala atau transmisi mengenai berita dan hasil-hasil penelitian mengenai media.

Sedangkan Lasa (1994) mengemukakan bahwa "jurnal ialah terbitan dalam bidang tertentu oleh instansi, badan, organisasi profesi maupun lembaga keilmuan. Terbit secara berkala dan teratur berisi informasi ilmiah, hasil penelitian, prosiding seminar, maupun pertemuan ilmiah yang lain (p. 16)".

Berdasarkan pendapat di atas, dapat dijelaskan bahwa jurnal merupakan suatu terbitan berkala yang berbentuk majalah yang isinya bersifat informasi ilmiah mengenai penemuan suatu karya mutakhir dalam kajian ilmu pengetahuan.

\section{Jurnal Tercetak}

Sebagai sumber informasi mutakhir jurnal tercetak dan jurnal elektronik merupakan salah satu unsur dalam upaya menyebarkan ilmu pengetahuan terkini kepada pengguna perpustakaan.

Dalam Buku Pegangan Gaya Penulisan, Rifai (1995: 57.95) mengemukakan bahwa Jurnal tercetak adalah terbitan berkala yang berbentuk pamplet berisi bahan yang sangat diminati orang saat diterbitkan. Bila dikaitkan dengan kata ilmiah di belakang kata jurnal berarti terbitan berkala yang berbentuk pamplet yang berisi bahan ilmiah yang sangat diminati orang saat diterbitkan.

Berdasarkan pendapat di atas, dapat diketahui bahwa jurnal tercetak merupakan terbitan berkala yang isinya bersifat informasi ilmiah mengenai penemuan suatu karya mutakhir dalam kajian ilmu pengetahuan yang banyak diminati pengguna yang membutuhkan informasi.

\section{Jurnal Elektronik}

Jurnal elektronik merupakan jurnal yang berbentuk digital/tidak tercetak atau dikenal dengan jurnal online, sebagaimana para pakar berikut mendefinisikan tentang jurnal elektronik, antara lain :

Tresnawan (2005), mengemukakan bahwa "Jurnal elektronik adalah terbitan serial seperti bentuk tercetak tetapi bentuk elektronik, biasanya terdiri dari tiga format, yaitu teks, tcks dan grafik, sertafull image (dalam bentuk pdf) (p. 1)".

Adapun menurut LIP1 (2005), "Jurnal clektonik (e-journal) adalah sarana berbasis web untuk mengelola sebuah jurnal ilmiah maupun non ilmiah. Sarana ini disediakan sebagai wadah bagi pengelola, penulis dan pembaca karya-karya ilmiah (p. 1)".

Berdasarkan pendapat di atas, dapat dinyatakan bahwa jurnal elektronik merupakan jurnal yang tersedia melalui media elektronik atau web yang telah diformat secara khusus untuk dapat diakses oleh pengguna yang membutuhkan informasi ilmiah.

\section{Pemanfaatan Jurnal Elcktronik}

Pemanfaatan jurnal elektronik merupakan kegiatan atau aktivitas pengguna dalam menggunakan jurnal dalam hal mencari informasi 
yang dibutuhkan. Informasi dalam jurnal bersifat ilmiah serta mutakhir dan melingkupi barbagai cabang ilmu pengetahuan.

Definisi di atas merupakan pengembangan dari pengertian pemanfaatan menurut kamus besar bahasa Indonesia (2002) yang menyatakan bahwa "Pemanfaatan mengandung arti yaitu proses, cara, dan perbuatan memanfaatkan sesuatu untuk kepentingan sendiri (p. 711)".

\section{Perbandingan Jurnal Elektronik dengan Jurnal Tercetak}

Jurnal elektronik merupakan bagian dari koleksi terbitan berseri dimana memiliki kelebihan dibandingkan dengan jurnal tercetak. Hal ini menyebabkan pengguna lebih memilih menggunakan jurnal elektronik dibandingkan jurnal tercetak, selain hemat waktu juga menghemat biaya dan tenaga, sesuai dengan pendapat Tresnawan (2005: 2) yang menyatakan bahwa:

"Dibandingkan dengan jurnal tercetak jurnal elektronik memiliki beberapa kelebihan, diantaranya dari segi kemuktahiran. Jurnal elektronik sering kali sudah terbit sebelum jurnal cetak diterbitkan sehingga dalam kecepatan penerimaan informasi jauh lebih menguntungkan.

Selanjutnya mengenai perbandingan jurnal elektronik dengan jurnal tercetak menurut Tresnawan (2005) dapat dipaparkan pada tabel berikut ini :

Tabel 1. Perbandingan Jurnal Elektronik dan Jurnal Tercetak

\begin{tabular}{|c|c|c|c|}
\hline No & Kriteria & Elektronik & Tercetak \\
\hline I & Kemuktahiran & Mutakhir & Mutakhir \\
\hline 2 & Kecepatan diterim & Cepat & Lambat \\
\hline 3 & Penyimpanan & $\begin{array}{l}\text { menghemat } \\
\text { tempat }\end{array}$ & $\begin{array}{l}\text { memerlukan } \\
\text { banyak tempat }\end{array}$ \\
\hline 4 & Pemanfaatan & $24 \mathrm{Jam}$ & Terbatas Jam buka \\
\hline 5 & $\begin{array}{l}\text { Kesempatan } \\
\text { akses }\end{array}$ & $\begin{array}{l}\text { Bisa } \\
\text { bersamaan }\end{array}$ & Bergantian \\
\hline 6 & Penelusuran & Otomatis tersedia & Harus dibuat \\
\hline 7 & $\begin{array}{l}\text { Waktu } \\
\text { penelusuran }\end{array}$ & Cepat & Lama \\
\hline 8 & Keamanan & Lebih aman & Kurang aman \\
\hline 9 & Manipulasi & Sangat & Tidak bisa \\
\hline 10 & $\begin{array}{l}\text { Dokumen } \\
\text { Langganan } \\
\text { dengan } \\
\text { harga yang sama }\end{array}$ & $\begin{array}{l}\text { mudah } \\
\text { Judul biasa } \\
\text { lebih } \\
\text { Banyak }\end{array}$ & $\begin{array}{l}\text { Judul lebih } \\
\text { sedikit }\end{array}$ \\
\hline 11 & $\begin{array}{l}\text { Harga total } \\
\text { Langganan }\end{array}$ & $\begin{array}{l}\text { Jaub lebih } \\
\text { murah }\end{array}$ & Lebih mahal \\
\hline
\end{tabular}

Tabel 1 di atas, menunjukkan bahwa jurnal elektronik lebih banyak memiliki nilai lebih dibandingkan dengan jurnal tercetak baik dari aspek kemuktahiran, penyimpanan, serta pemanfaatannya. Dengan adanya kelebihan yang dimiliki jurnal elektronik dapat lebih memudahkan pengguna dalam mencari informasi khususnya dalam hal penelusuran jurnal online/elektronik, Namun disamping itu jurnal elektronik memiliki kelemahan, yaitu untuk mengakses jurnal harus melalui komputer yang tentunya membutuhkan energi listrik, jadi apabila terjadi pemadaman listrik jurnal online tidak dapat diakses.

\section{Konsep Kebutuhan Informasi}

Pada umumnya pengguna perpustakaan membutuhkan informasi yang cepat dan beragam, artinya pengguna perpustakaan tidak hanya membutuhkan informasi sesuai bidang yang sedang didalami tetapi juga sering kali membutuhkan informasi lain untuk memperkaya ilmunya, untuk itu dibutuhkan pelayanan perpustakaan yang dapat memuaskan pengguna perpustakaan. Mendukung pernyataan di atas, Chaudry (1993:8) mengemukakan:

"Bila pengelola informasi bisa memahami kebutuhan informasi pemakai, maka akan membantu dalam pengembangan layanan perpustakaan, diantaranya: a) peningkatan apa saja yang dapat dilakukan untuk memanfaatkan layanan yang sudah ada, b) usaha apa saja yang harus dilakukan agar layanan dan sumber informasi perpustakaan diketahui secara lebih baik oleh pemakai, dan c) program kerja apa saja yang dapat dijalankan untuk mempertemukan layanan yang ada dengan kebiasaan pencarian informasi".

Bagi pihak perpustakaan sebagai penyedia informasi, dengan memahami kebutuhan informasi pemakai dapat menjadikan tujuan perpustakaan akan lebih mudah tercapai.

Sehubungan dengan kebutuhan informasi pengguna. Chowdhury (1999), menyatakan bahwa kebutuhan informasi merupakan suatu konsep yang samar.

Sedangkan menurut Hartono (2000: 692) "Informasi dapat didefinisikan sebagai hasil pengolahan data dalam suatu bentuk yang lebih berarti bagi penerimanya yang menggambarkan suatu kejadian (events) yang nyata (fact) yang 
digunakan untuk pengambilan keputusan.

Sesuai dengan pendapat di atas, dapat dijelaskan bahwa definisi kebutuhan informasi adalah sesuatu yang datang dari diri sesorang atas tuntutan untuk mengetahui sesuatu dalam rangka mengatasi segala kekurangan pengetahuannya.

\section{METODE PENELITIAN}

Metode penelitian adalah cara ilmiah yang digunakan untuk melakukan penelitian. Metode yang digunakan dalam penelitian ini adalah deskriptif dengan pendekatan komparatif. Alasan menggunakan pendekatan komparatif adalah untuk menguji teori sehingga ditemukan perbedaan dan kesamaan antara variabel yang satu dengan variabel yang lainnya.

\section{Populasi dan Sampel}

Populasi dalam penelitian ini adalah anggota Perpustakaan USU cabang Kedokteran tahun 2014 yang berjumlah 540 orang dari mahasiswa S1 Program Studi Kedokteran Umum.

Sampel dalam penelitian ini, peneliti mengunakan rumus Slovin, maka yang menjadi sampel pada penelitian ini adalah : 84 Orang. Dalam menentukan sampel digunakan teknik aksidental.

\section{Instrumen Penelitian}

Setiap penelitian membutuhkan alat untuk mengumpulkan data yang disebutkan dengan instrumen penelitian. Instrumen yang digunakan untuk memperoleh data dalam penelitian ini adalah kuesioner.

\section{Analisis Data}

Dalam penelitian ini, data dianalisis dengan menggunakan metode deskriptif, yaitu metode dimana data dikumpulkan, disusun, diinterpretasikan, dan dianalisa sehingga memberikan keterangan yang lengkap bagi permasalahan yang dihadapi.

Selanjutnya data yang diperoleh akan ditabulasikan dengan menyusun kedalam tabel-tabel kemudian dihitung presentasinya, dan diinterpretasikan.

\section{HASILDAN PEMBAHASAN}

\section{Frekuensi Pemanfaatan Jurnal Cetak dengan Jurnal Elektronik}

Hasil penelitian ini menunjukkan bahwa responden yang memanfaatkan jurnal tercetak dalam seminggu sebanyak 5 responden $(5,9 \%)$ menyatakan 6 kali, 10 responden $(11,9 \%)$ menyatakan $4-5$ kali, 57 responden $(67,8 \%)$ menyatakan $2-3$ kali dan 12 responden $(14,2 \%)$ menyatakan 1 kali. Sedangkan data untuk jurnal elektronik dapat diketahui bahwa responden yang memanfaatkan jurnal elektronik dalam seminggu sebanyak 50 responden $(59,5 \%)$ menyatakan 6 kali, 25 responden $(29,7 \%)$ menyatakan $4-5$ kali, 4 responden $(4,7 \%)$ menyatakan $2-3$ kali dan 5 responden $(5,9 \%)$ menyatakan $1 \mathrm{kali}$.

Persentase di atas dapat dinyatakan bahwa sebagian besar mahasiswa menyatakan 2-3 kali memanfaatkan jurnal tercetak dalam seminggu sedangkan sebagian besar mahasiswa menyatakan 6 kali dan hampir setengahnya mahasiswa menyatakan 4-5 kali memanfaatkan jurnal elektronik dalam seminggu. Hal ini dikarenakan perolehan informasi yang lama, penggunaan dan akses jurnal tercetak yang terbatas hanya dapat dimanfaatkan pada jam buka perpustakaan USU Cabang Kedokteran.

Berdasarkan perbandingan data di atas dapat disimpulkan bahwa jurnal elektronik lebih banyak dimanfaatkan oleh mahasiswa dari pada jurnal tercetak.

\section{Pemanfaatan Jurnal}

Pemanfaatan jurnal tercetak di Perpustakaan USU Cabang Kedokteran dapat diketahui bahwa responden yang memanfaatkan jurnal tercetak yang ada di Perpustakaan USU Cabang Kedokteran sebanyak 5 responden $(5,9 \%)$ menyatakan selalu, 12 responden $(14,2 \%)$ menyatakan sering, 55 responden $(65,4 \%)$ menyatakan kadang-kadang dan 12 responden $(14,2 \%)$ menyatakan tidak pernah. Sedangkan data untuk jurnal elektronik dapat diketahui bahwa responden yang memanfaatkan jurnal elektronik yang ada di Perpustakaan USU Cabang Kedokteran sebanyak 20 responden $(23,8 \%)$ menyatakan selalu, 51 responden $(60,7 \%)$ menyatakan sering, 7 responden $(8,3 \%)$ menyatakan kadang-kadang dan 6 responden $(7,1 \%)$ menyatakan tidak pernah.

Berdasarkan uraian di atas dapat diinterpretasikan bahwa sebagian besar mahasiswa menyatakan kadang-kadang memanfaatkan jurnal tercetak sedangkan sebagian besar mahasiswa menyatakan sering memanfaatkan jurnal elektronik yang ada di Perpustakaan USU Cabang Kedokteran. 
Mahasiswa merasa kesulitan dalam pencarian informasi yang dibutuhkan terutama pada hasil-hasil penelitian dan penyelesaian tugas. Jurnal tercetak hanya dapat dimanfaatkan jika seseorang sedang membaca artikel jurnal tercetak yang hanya terdiri dari l eksemplar, maka pengguna yang ingin membacanya harus menunggu sampai selesai. Untuk jurnal elektronik memiliki link atau kaitan antara satu artikel dengan artikel lainnya yang disitir sehingga pembaca dapat mengakses artikel asli yang disitirnya tanpa kesulitan mencarinya.

Perbandingan di atas dapat disimpulkan bahwa mahasiswa yang datang di Perpustakaan USU Cabang Kedokteran sering memanfaatkan jurnal elektronik dari pada jurnal tercetak

Hasil penelitian ini dapat diketahui bahwa responden yang memanfaatkan jurnal tercetak yang ada di Perpustakaan USU Cabang Kedokteran sebanyak 5 responden $(5,9 \%)$ menyatakan mencatat informasi yang dibutuhkan, 50 responden $(71,4 \%)$ menyatakan membaca ditempat, dan 29 responden $(34,5 \%)$ menyatakan lain-lain. Sedangkan data untuk jurnal elektronik dapat diketahui bahwa responden yang memanfaatkan jurnal elektronik yang ada di Perpustakaan USU Cabang Kedokteran sebanyak 5 responden $(5,9 \%)$ menyatakan mencatat informasi yang dibutuhkan, 16 responden $(19 \%)$ menyatakan membaca ditempat, dan 63 responden (75\%) menyatakan lain-lain.

Berdasarkan uraian di atas dapat interpretasikan bahwa sebagian besar mahasiswa menyatakan membaca ditempat dalam memanfaatkan jurnal tercetak yang ada di Perpustakaan USU Cabang Kedokteran dan harnpir setengahnya menyatakan lain-lain, seperti mernfotokopi jurnal tercetak dalam penyelesaian tugas-tugas dari dosen. Sedangkan untuk jurnal elektronik pada umumnya mahasiswa menyatakan lain-lain dalam memanfaatkan jurnal elektronik, seperti mendownload dan mencetak/print informasi yang dibutuhkan mahasiswa dalam penyelesaian tugas kuliah dan pencarian hasil - hasil penelitian ilmiah.

Perbandingan data di atas dapat disimpulkan bahwa pada umumnya mahasiswa memanfaatkan jurnal elektronik dengan men-download, mencetak/print sedangkan sebagian besar mahasiswa memanfaatkan jurnal tercetak dengan cara membaca ditempat.

\section{Tujuan memanfaatkan jurnal}

Hasil penelitian ini menunjukkan bahwa tujuan responden memanfaatkan jurnal tercetak sebanyak
15 responden $(17,8 \%)$ menyatakan menyelesaikan tugas, 56 responden $(66,6 \%)$ menyatakan menambah wawasan, 13 responden $(15,4 \%)$ menyatakan mencari informasi dan 0 responden $(0 \%)$ menyatakan lain-lain. Sedangkan data untuk jurnal elektronik dapat diketahui bahwa tujuan responden memanfaatkan database jurnal elektronik yang ada di Perpustakaan USU cabang Kedokteran sebanyak 64 responden $(76,1 \%)$ menyatakan menyelesaikan tugas, 18 responden $(21,4 \%)$ menyatakan menambah wawasan, 2 responden $(2,3 \%)$ menyatakan mencari informasi dan 0 responden $(0 \%)$ menyatakan lain-lain.

Berdasarkan uraian di atas dapat diinterpretasikan bahwa sebagian besar mahasiswa menyatakan tujuan memanfaatkan jurnal tercetak yang ada di Perpustakaan USU Cabang Kedokteran untuk menambah ilmu pengetahuan dan informasi terbaru. Sedangkan sebagian besar mahasiswa menyatakan memanfaatkan database jurnal elektronik untuk menyelesaikan tugas. Tersedianya jurnal elektronik di Perpustakaan menjadi salah satu sumber informasi yang dibutuhkan bagi sivitas akademika, khususnya mahasiswa dalam perolehan informasi. Pengaksesan jurnal elektronik tidak hanya dari lingkungan Perpustakaan Perguruan Tinggi dari luar Perpustakaan pengguna dapat mengakses.

Perbandingan data di atas dapat disimpulkan bahwa tujuan mahasiswa memanfaatkan jurnal tercetak untuk menambah wawasan sedangkan mahasiswa memanfaatkan jurnal elektronik untuk penyelesaian tugas-tugas kuliah yang diberikan dosen yang berkaitan dengan penelitian.

\section{Kebutuhan Informasi Mahasiswa}

Hasil penelitian ini dapat diketahui bahwa responden menyatakan jurnal tercetak di Perpustakaan USU Cabang Kedokteran sesuai dengan kebutuhan informasi sebanyak 8 responden $(9,5 \%)$ menyatakan sangat sesuai, 56 responden $(66,6 \%)$ menyatakan kurang sesuai, 13 responden $(15,4 \%)$ menyatakan sesuai dan 7 responden $(8,3 \%)$ menyatakan tidak sesuai. Sedangkan data untuk jurnal elektronik dapat diketahui bahwa responden menyatakan artikel jurnal elektronik di Perpustakaan USU Cabang Kedokteran sesuai dengan kebutuhan informasi sebanyak 8 responden $(9,5 \%)$ menyatakan sangat sesuai, 68 responden $(80,9 \%)$ menyatakan sesuai, 
4 responden $(4,7 \%)$ menyatakan kurang sesuai dan 4 responden $(4,7 \%)$ menyatakan tidak sesuai.

Persentase di atas dapat dinyatakan bahwa sebagian besar mahasiswa menyatakan kurang sesuai dengan jurnal tercetak yang ada di Perpustakaan USU Cabang Kedokteran dengan kebutuhan informasi sedangkan pada umumnya mahasiswa menyatakan sesuai. Alasan mahasiswa bahwa jurnal tercetak di Perpustakaan USU Cabang Kedokteran biasa-biasa saja, belum sesuai dalam penyelesaian tugas-tugas kuliah dan tingkat relevansi antara kebutuhan pengguna dengan koleksi masih rendah.

Perbandingan data di atas dapat disimpulkan bahwa jurnal elektronik yang ada di Perpustakaan USU Cabang Kedokteran sesuai dengan kebutuhan informasi mahasiswa daripada jurnal tercetak.

Jumlah jurnal tercetak di Perpustakaan USU Cabang Kedokteran sudah memenuhi kebutuhan informasi sebanyak 8 responden $(9,5 \%)$ menyatakan sangat memenuhi, 14 responden $(16,6 \%)$ menyatakan memenuhi, 58 responden $(66,6 \%)$ menyatakan kurang memenuhi dan 4 responden $(4,7 \%)$ menyatakan tidak memenuhi. Sedangkan data untuk jurnal elektronik dapat diketahui bahwa responden menyatakan jumlah artikel jurnal elektronik di Perpustakaan USU Cabang Kedokteran sudah memenuhi kebutuhan informasi sebanyak 14 responden $(16,6 \%)$ menyatakan sangat memenuhi, 53 responden $(63 \%)$ menyatakan memenuhi, 12 responden $(14,4 \%)$ menyatakan kurang memenuhi dan 5 responden $(5,9 \%)$ menyatakan tidak memenuhi.

Persentase di atas dapat dinyatakan bahwa sebagian besar mahasiswa menyatakan kurang memenuhi jumlah jurnal tercetak yang ada di Perpustakaan USU Cabang Kedokteran untuk kebutuhan informasi sedangkan pada umumnya mahasiswa menyatakan memenuhi jumlah artikel jurnal elektronik yang ada di Perpustakaan USU Cabang Kedokteran. Alasan mahasiswa adalah bahwa jumlah artikel jurnal sesuai untuk kebutuhan responden dalam pencarian informasi dan penyelesaian tugas. Jumlah database jurnal elektronik Perpustakaan yaitu 20.448 judul artikel daripada jumlah koleksi jurnal tercetak sampai tahun 2014 berjumlah 115 judul dengan 386 eksemplar bidang kedokteran dan kesehatan.

Berdasarkan perbandingan data di atas dapat disimpulkan bahwa jumlah jurnal elektronik yang ada di Perpustakaan memenuhi daripada jurnal tercetak.

\section{Kepentingan Informasi dalam Jurnal Tercetak dengan Jurnal Elektronik}

Hasil penelitian ini dapat diketahui bahwa informasi yang terdapat pada jurnal tercetak sebanyak 32 responden (38\%) menyatakan sangat penting, 52 responden $(62 \%)$ menyatakan penting, 0 responden $(0 \%)$ menyatakan kurang penting dan 0 responden $(0 \%)$ menyatakan tidak penting. Sedangkan data untuk jurnal elektronik dapat diketahui bahwa informasi yang terdapat pada artikel jurnal elektronik sebanyak 63 responden (75\%) menyatakan sangat penting, 21 responden $(25 \%)$ menyatakan penting, sebanyak 0 responden $(0 \%)$ menyatakan kurang penting, 0 responden $(0 \%)$ menyatakan tidak penting.

Persentase di atas dapat dinyatakan seluruhnya mahasiswa menyatakan penting untuk perolehan informasi yang dibutuhkan dalam jurnal tercetak dan jurnal elektronik. Peranan jurnal sebagai informasi rujukan dalam proses penelitian sangat penting untuk menghasilkan penelitian yang berkualitas. Dalam penelitian ilmiah referensi yang utama paling akurat adalah jurnal imiah.

Berdasarkan perbandingan data di atas dapat disimpulkan bahwa jurnal tercetak dengan jurnal elektronik penting bagi mahasiswa yang ada di Perpustakaan USU cabang Kedokteran.

\section{Kemuktahiran Jurnal}

Hasil penelitian ini menunjukkan bahwa koleksi jurnal tercetak mutakhir (up to date) sebanyak 12 responden $(14,2 \%)$ menyatakan sangat setuju, 13 responden $(15,4 \%)$ menyatakan setuju, 43 responden $(51,1 \%)$ menyatakan kurang setuju dan 16 responden (19\%) menyatakan tidak setuju. Sedangkan data untuk jurnal elektronik dapat diketahui bahwa database jurnal elektronik mutakhir (up to date) sebanyak 52 responden $(61,9 \%)$ menyatakan sangat setuju, 20 responden $(23,8 \%)$ menyatakan setuju, 5 responden $(5,9 \%)$ menyatakan kurang setuju, 7 responden $(8,3 \%)$ menyatakan tidak setuju.

Uraian di atas dapat diinterpretasikan bahwa sebagian besar mahasiswa menyatakan kurang setuju jurnal tercetak di Perpustakaan USU Cabang Kedokteran mutakhir (up to date). Hal ini dikarenakan ada koleksi jurnal tercetak dari Perpustakaan USU Cabang Kedokteran yaitu Majalah Kedokteran Nusantara tidak diterbitkan kembali. Sedangkan untuk jurnal elektronik pada umumnya mahasiswa menyatakan setuju database jurnal elektronik mutakhir (up to date) sehingga dapat memenuhi kebutuhan informasi baik untuk 
kepentingan penelitian, penyelesaian tugas, studi kasus, tesis serta disertasi. Jurnal sangat dibutuhkan sebagai sumber dalam memecahkan masalah penelitian yang sifatnya mutakhir.

Berdasarkan perbandingan di atas dapat disimpulkan bahwa jurnal elektronik mutakhir (up to date) daripada jurnal tercetak.

\section{Kesulitan dalam Memanfaatkan Jurnal}

Hasil penelitian ini dapat diketahui bahwa responden merasa kesulitan dalam memanfaatkan jurnal tercetak sebanyak 19 responden $(22,6 \%)$ menyatakan selalu, 43 responden $(51,1 \%)$ menyatakan sering, 13 responden $(15,4 \%)$ menyatakan kadang-kadang dan 9 responden $(10,7 \%)$ menyatakan tidak pernah. Sedangkan data pada jurnal elektronik dapat diketahui bahwa responden merasa kesulitan dalam memanfaatkan artikel jurnal elektronik sebanyak 5 responden $(5,9 \%)$ menyatakan selalu, 13 responden $(13 \%)$ menyatakan sering, 20 responden $(23,8 \%)$ menyatakan kadang-kadang dan 48 responden $(57,1 \%)$ menyatakan tidak pernah.

Uraian di atas dapat diinterpretasikan bahwa sebagian besar mahasiswa menyatakan sering mengalami kesulitan dalam memanfaatkan jurnal tercetak di Perpustakaan USU Cabang Kedokteran dan sebagian besar mahasiswa menyatakan tidak pernah mengalami kesulitan dalam memanfaatkan artikel jurnal elektronik, mahasiswa hanya sebagian kecil menyatakan kadang-kadang mengalami kesulitan dalam memanfaatkan artikel jurnal elektronik di Perpustakaan USU Cabang Kedokteran.

Berdasarkan perbandingan data di atas dapat disimpulkan bahwa jurnal tercetak sering mengalami kesulitan daripada jurnal elektronik, hanya sebagian kecil mengalami kesulitan.

Kesulitan yang dihadapi responden dalam memanfaatkan jurnal tercetak sebanyak 15 responden $(17,8 \%)$ menyatakan faktor bahasa, 41 responden $(48,8 \%)$ menyatakan sulit mendapatkan informasi, 28 responden $(33,3 \%)$ dan 0 responden $(0 \%)$ menyatakan lain-lain. Sedangkan data untuk jurnal elektronik dapat diketahui bahwa kesulitan yang dihadapi responden dalam memanfaatkan artikel jurnal elektronik yang ada di Perpustakaan USU Cabang Kedokteran sebanyak 30 responden $(35,7 \%)$ menyatakan faktor bahasa, 0 responden $(0 \%)$ menyatakan sulit mendapatkan informasi, 0 responden $(0 \%)$ menyatakan penggunaan yang terbatas dan 54 responden $(64,2 \%)$ menyatakan lainlain.
Uraian di atas dapat diinterpretasikan bahwa hampir setengahnya mahasiswa menyatakan kesulitan dalam memanfaatkan jurnal tercetak adalah sulit mendapatkan informasi yang dibutuhkan ketika menelusur dan hanya bisa dimanfaatkan hanya akses tunggal artinya seseorang membaca artikel jurnal tercetak hanya terdiri 1 eksemplar, maka mahasiswa yang ingin membaca jurnal yang sama harus menunggu. Sedangkan pada jurnal elektronik bahwa sebagian besar mahasiswa menyatakan lain-lain, seperti akses internet yang lambat dan aliran listrik terputus sehingga mahasiswa yang memanfaatkan artikel jurnal elektronik mengalami kendala saat mencari informasi yang dibutuhkan.

Berdasarkan perbandingan data diatas dapat disimpulkan bahwa kesulitan yang dihadapi mahasiswa saat memanfaatkan jurnal tercetak adalah sulit mendapatkan informasi sedangkan jurnal elektronik kesulitannya adalah akses internet yang lambat dan aliran listrik yang terputus.

\section{E. KESIMPULAN}

Berdasarkan analisis dari hasil penelitian yang diuraikan di atas dapat disimpulkan sebagai berikut:

1. Secara umum mahasiswa SI Program Studi Kedokteran Umum menggunakan database jurnal elektronik dibanding jurnal tercetak. Jurnal tercetak sulit untuk menelusur, penggunaan dan pelayanan yang terbatas, sedangkan jurnal elektronik memiliki sistem penelusuran yang cepat dan mudah.

2. Dalam seminggu sebagian besar mahasiswa memanfaatkan koleksi jurnal tercetak sebanyak 2-3 kali sedangkan sebagian besar mahasiswa memanfatkan jurnal elektronik di Perpustakaan USU Cabang Kedokteran sebanyak 6 kali.

3. Jumlah jurnal elektronik yang ada di Perpustakaan USU Cabang Kedokteran memenuhi daripada jurnal tercetak, hal ini dikarenakan jumlah jurnal tercetak berjumlah 115 judul dengan 386 eksemplar tidak sesuai untuk kebutuhan informasi mahasiswa sedangkan jumlah database jurnal elektronik berjumlah 20.448 judul artikel.

4. Jurnal elektronik lebih mutakhir (up to date) daripada jurnal tercetak, hal ini dikarenakan koleksi jurnal tercetak di Perpustakaan USU Cabang Kedokteran ada yang tidak diterbitkan kembali seperti Majalah Kedokteran Nusantara.

5. Kesulitan mahasiswa dalam memanfaatkan 
jurnal tercetak hampir setengah mahasiswa sulit mendapatkan informasi dan sebagian kecil mahasiswa menyatakan penggunaan yang terbatas dan faktor bahasa. Untuk jurnal elektronik sebagian besar kesulitan mahasiswa adalah akses internet yang lambat dan aliran listrik sering terputus.

\section{DAFTAR PUSTAKA}

Anwar, A. (2012). Optimalisasi E- journal bagi mahasiswa S1. Retrieved December 06, 2012, from http://ahmadcahperpus.blogspot.com.

Chaudry, A.S. (1993). Information needs and their satisfaction in a utility company. Libraries Review, 42(1).

Chitraprita. (2009). Jurnal. Retrieved January 24, 2013, from http:/Chitraprita.blogspot.com.

Chowdury. G.G.(1999). Introduction to modern information retrieval. London: Library Association Publishing.

Hadi, S. (2001). Metode Penelitian. Yogyakarta: Yayasan Penelitian Fakultas 1lmu Psikologi Universitas Gajah Mada.

Hartono, B. (2000). Sistem dan Pelayanan Informasi. Jakarta: Arga Kencana Abadi.

HighBeamTM Research, Inc. (2012). Encyclopedia. Retrieved December 22, 2012, from www.encyclopedia.com.
Ishak. (2006). Kebutuhan Informasi Mahasiswa Program Pendidikan Dokter Spesialis (PPDS) FK-UI dalam Memenuhi Tugas Journal Reading. Jurnal Pustaha, vol.2. Medan : DSPI.

Lasa Hs. (1994). Pengelolaan Terbitan Berseri. Yogyakarta: Kanisius

Lcmbaga Ilmu Pengetahuan Indonesia. (2005). Jurnal Online. Retrieved December 23, 2012, from $\mathrm{bttp}: /$ www.jurnal.lipi.gp.id/utama.

Muntashir. (2005). Pemanfaatan jurnal elektronik oleh mahasiswa program Pendidikan Dokter spesialis ilmu penyakit dalam di Perpustakaan USU. Skripsi. Medan: Fakultas Sastra USU.

Murniati, A. (2012). Pemanfaatan e-journal dan ebookoleh mahasiswa di lingkungan Fakultas Tarbiyah dan Keguruan UIN SUSK Riau. Retrieved February 07, 2013, from http:// jurnal.upi.edu/file/jurnal_tugas_prof_ishak.do $c x$.

Nazir, M. (2005). Metode penelitian. Ghalia Indonesia.

Salim, P. (2002). Kamus Besar Bahasa Indonesia Kontemporer. Jakarta: Modern English Press.

Tresnawan, A. (2005). Jurnal Elektronik: Berbagi Pengalaman Proses berlangganan Jurnal Online di UPT Perpustakaan UNISBA. Retrieved $\mathrm{D}$ e c e m b e r 07,2012 from http://www.ipi.or.id.materi//PI-kiat.doc. 